\title{
First Total Synthesis and Structural Confirmation of C13- Butylrubber Oligomers
}

\author{
Fabrizio Minicone, ${ }^{[a]}$ Robin Attrill, ${ }^{[b]}$ Michael Hodgson, ${ }^{[b]}$ Katherine Wheelhouse ${ }^{[b]}$ and Adrian Dobbs ${ }^{*[a]}$
}

Abstract: The first total synthesis of an important $\mathrm{C} 13$ butyl rubber oligomer is reported. The structure of the oligomer, which is an important and potentially toxic extractable and leachable component of elastomeric closures, is confirmed by synthesis for the first time. The method described is scalable, making large quantities of the oligomer available for the first time for AMES toxicity studies. The challenging synthesis commences with isophorone and the key steps of the synthesis involve the development of highly novel dithoacetal chemistry, cuprate addition and Tebbe olefination.

Dedicated with deep fondness and respect to Professor Istvan E. Markó (1956-2017), who liked a challenging total synthesis!

\section{Introduction}

Elastomeric or rubber closures ('seals') have found widespread application, particularly in the pharmaceutical industry, frequently as components for injection systems, such as in stoppers and caps Elastomeric closures are particularly attractive and widely used owing to a number of beneficial features, including their ability to reseal. However, the composition of such rubbers is highly complex and may comprise many components, including the elastomer (basic unit) as well as anti-oxidants, fillers, curing agents, activators and accelerators. While the production of the rubbers has improved greatly over the last 30 years, there still remains the problems of impurities within the rubbers, and the potential for leaching of materials from the rubbers into the vial contents.

A series of $\mathrm{C} 13$ and $\mathrm{C} 21$ oligomers, together with their halogenated derivatives, have long been postulated as the key extractable components. ${ }^{1}$ Through a large-scale rubberextraction/isolation/purification technique, sufficient material has been isolated to determine the molecular formulae of these oligomers as $\mathrm{C}_{13} \mathrm{H}_{24}$ and its halogenated derivatives $\mathrm{C}_{13} \mathrm{H}_{23} \mathrm{Br}$ or $\mathrm{C}_{13} \mathrm{H}_{23} \mathrm{Br}$, and $\mathrm{C}_{21} \mathrm{H}_{40}$. Furthermore, the structures of the

[a] F. Minicone, A.P. Dobbs*

Department of Pharmaceutical, Chemical \& Environmental Sciences University of Greenwich

Grenville Building, Chatham Maritime, Kent ME4 4TB, UK.

A.Dobbs@gre.ac.uk

http://www.gre.ac.uk/engsci/study/pharchemenv/staff/adrian-dobbs

[b] M. D. Hodgson, R. Attrill, K. Wheelhouse

Medicines Research Centre

GlaxoSmithKline

Gunnels Wood Road, Stevenage, Hertfordshire, SG1 2NY, UK.

Supporting information for this article is given via a link at the end of the document. oligomers have been proposed to be (1-3) on the basis of extensive NMR studies. ${ }^{1,2}$

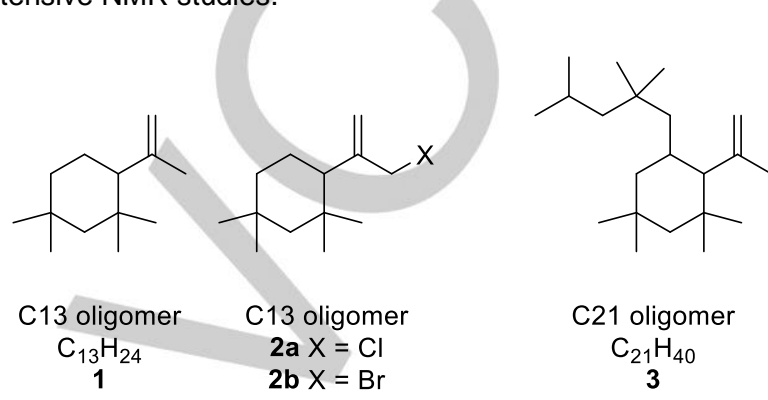

Figure 1. Proposed structures of butyl rubber oligomers.

It is proposed that these oligomers are formed during the polymerization process by an intramolecular cyclisation process, combining one isoprene and two isobutylene units (Scheme 2).

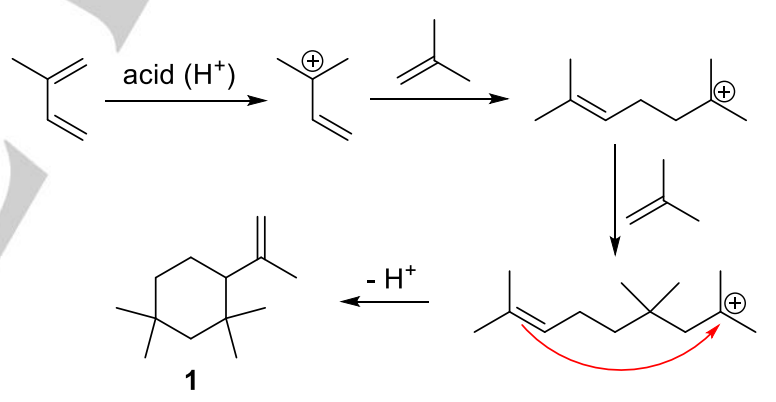

Scheme 1. Proposed mechanism of formation of the $\mathrm{C}_{13} \mathrm{H}_{24}$ oligomer.

Compounds (1) and (3) have recently become commercially available and are obtained via extraction and purification from a large number of rubber seals! $!^{2}$ It is reported that they can be present in quantities between $0.05-0.6 \mathrm{~g}$ per $\mathrm{kg}$ material. Extractable and leachable studies have shown that in certain instances, these may leach out of the rubber and into the drug product. Crucially, there is no toxicity data about these compounds, mainly owing to being only ever isolated in these minute quantities. A completed syntheses of these compounds is therefore urgent, both for verification of the structural assignments and to provide sufficient material for further toxicological evaluation via AMES tests. Herein, we report the first total synthesis of the $\mathrm{C} 13$ oligomer, (1) by a robust and scalable route. 


\section{Results and Discussion}

Obtaining the 1,2,4-substitution pattern was considered challenging from the outset, particularly given the steric bulk presented by the four methyl groups. A number of commercial compounds contain the two gem-dimethyl groups in the correct arrangements and were initially deemed to be suitable starting materials.

It is possible to access 3-(2-propenyl)-2,2,6,6tetramethylcyclohexanone starting (4) from carvone. ${ }^{3}$ Regrettably, all attempts to remove the carbonyl group were unsuccessful. Direct reduction of the ketone via Wolff-Kishner or Clemmensen reductions only gave unreacted starting material. Formation of a cyclic dithioacetal using ethane-1,2-dithiol, for subsequent reduction, was also unsuccessful, again with quantitative recovery of starting material. Lithium aluminium hydride reduction did give the corresponding alcohol (5), although attempts to remove this using radical methods were again unfruitful, with the alcohol unreactive under all attempted conditions (Scheme 2).

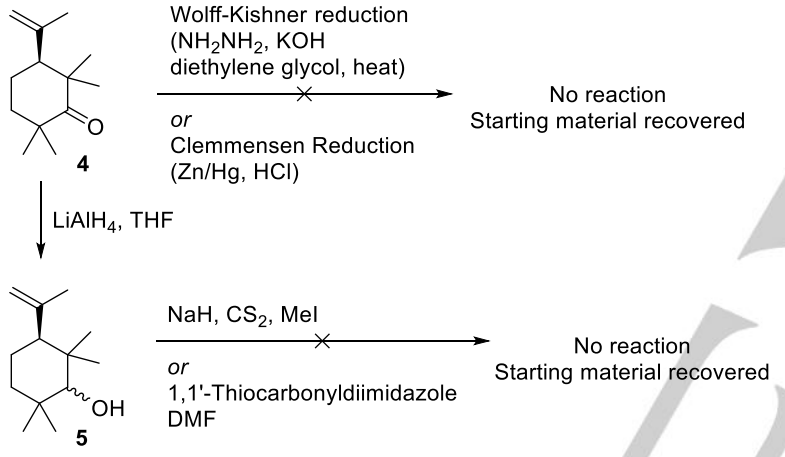

Scheme 2. Unsuccessful methods towards (1) starting from 3-(2-propenyl)2,2,6,6-tetramethylcyclohexanone.

It was possible to produce the mesylate (6) derived from (5), but not the tosylate (Scheme 3). Treatment with sodium borohydride or lithium aluminium hydride to displace the mesylate gave no reaction. Reaction of (6) with $L$-selectride gave a product lacking in the mesyl moiety and containing a terminal alkene, which was initially believed to be the desired target (1). GC-MS analysis showed two close running compounds, both giving identical mass spectra but with $m / z=178.32$, two mass units less than the proposed compound (1). Extensive NMR studies suggested that rather than reduction, the hydride had deprotonated the allylic$\mathrm{CH}_{3}$ group, which lead to intramolecular displacement of the mesylate to furnish the bridged cycloalkane (7), with the correct observed molecular weight. However, from the NMR spectra, it is impossible to discount the alternative structures (7a or $\mathbf{7 b}$ ), formed via direct $\mathrm{S}_{\mathrm{N}} 1$-type loss of the mesylate followed by carbocation rearrangement/ring contraction to the more stable carbocation and elimination, to give the various possible 5membered ring products (Scheme 3 ).

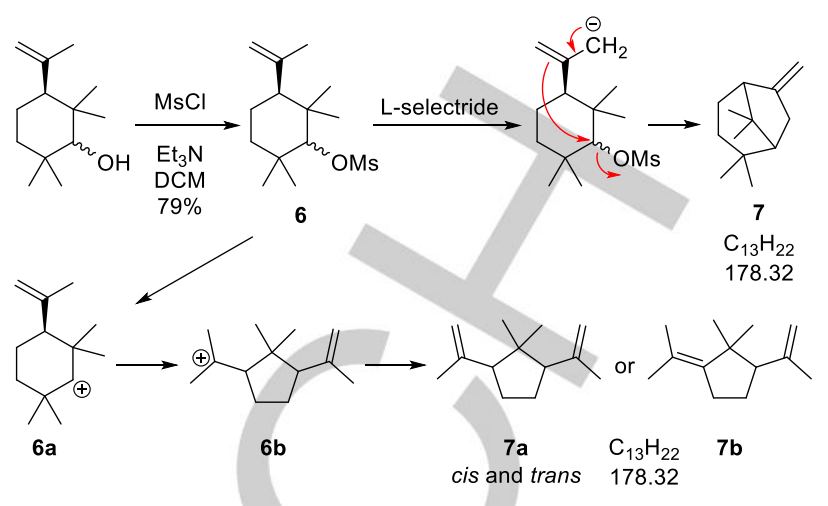

Scheme 3. Attempted mesylate displacement leading either to bicyclic product (7) or rearranged product $(\mathbf{7 a} / \mathbf{7 b})$

With no other suitable 1,2,4-substituted precursors being commercially available, ketone (8) was seen as a suitable starting material. Introduction of the formyl group, masked as an acetal, was facile and high yielding employing triethyl orthoformate and $\mathrm{TiCl}_{4}(\mathbf{9}, 72 \%)$. However, all attempts to remove the ketone were unsuccessful. Wolff-Kishner conditions, either with hydrazine or TBS-protected hydrazine, gave no reaction. Sodium borohydride reduction did afford the alcohol (10) in excellent yield, but regrettably any attempts to remove this either showed no reaction or gave a product suggestive of polymerization. Only treatment with dilute sulfuric acid gave any traces of the elimination product (11), and not in yields to be of any use.

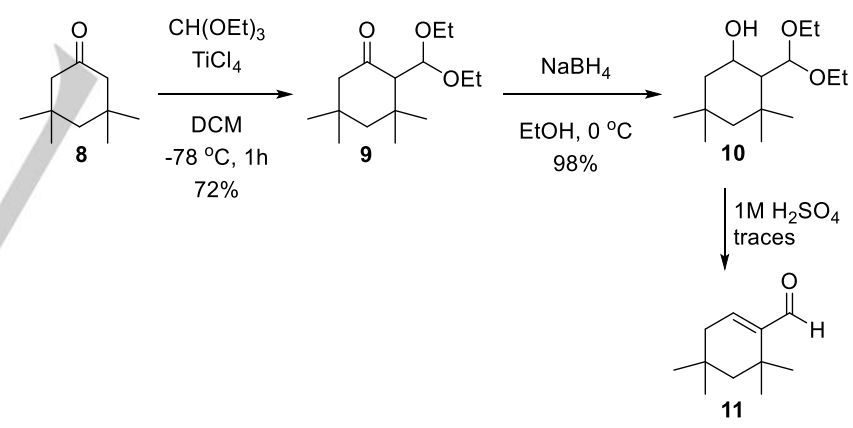

Scheme 4. Attempted route to (1) starting from $3,3,5,5$ tetramethylcyclohexanone.

The problems encountered in all these approaches were attributed to the two gem dimethyl groups present in the different starting materials. Therefore a novel approach was required that would not rely upon late stage removal of a ketone moiety. It was also envisaged that any successful route would not have the four problematic methyl groups present throughout the synthesis, but rather would introduce these at an appropriate stage in the synthesis.

It was proposed to employ an $\alpha$-oxoketene dithioacetal, ${ }^{4-6}$ derived from carbon disulfide, as the solution for introducing the required side chain, and then to introduce one of the problematic gemdimethyl groups at a later stage in the synthesis, once all 
necessary functional group interconversions were complete (Scheme 4). Starting from isophorone (11), reaction with potassium tert-butoxide and carbon disulfide installed the dithioacetal moiety (12), and $\mathrm{HgCl}_{2}$-mediated hydrolysis ${ }^{6}$ gave the thioester (13) in 58\% yield over the two steps. Treatment with sodium methoxide furnished the methyl ester (14) in $80 \%$ yield. ${ }^{7}$ It was at this stage that methyl cuprate addition to the $\alpha, \beta$ unsaturated system installed the fourth methyl group (15), obtained as a mixture of keto-enol tautomers (approximate 1.5:1 ratio). Reduction of the ketone with sodium borohydride proceeded smoothly as before, and this was protected as the mesylate, (16). Unlike before, elimination of the mesylate proceeded smoothly, presumably owing to the $\alpha, \beta$-unsaturated product (17) that was formed. Reduction of the alkene was achieved by hydrogenation in ethanol over $5 \% \mathrm{w} / \mathrm{w}$ palladium on charcoal. Reaction of the ester with trimethyl aluminium/TMEDA gave the ketone (18). This was finally converted to the alkene using the Tebbe reagent, to give the postulated $\mathrm{C} 13$ oligomer (1) in 10 steps and $3.4 \%$ overall yield. The new terminal alkene peaks were clearly visible at $\delta=4.64$ and $4.82 \mathrm{ppm}$, which were completely in agreement with the literature values.

Comparison of the NMR and mass spectra of (1) with a genuine sample of (1) and previously reported values ${ }^{1}$ confirmed that, for the first time, the $\mathrm{C} 13$ oligomer had been prepared synthetically away from the polymerisation approach. The two mass spectra were identical, both in the molecular ion and fragmentation pattern obtained. Therefore the proposed structure of (1) has finally been unambiguously confirmed by synthesis.

It was possible to prepare the chloro-derivative (2a) using the procedure of Brindisi et al, employing cerium trichloride and $\mathrm{NaOCl} .^{8}$

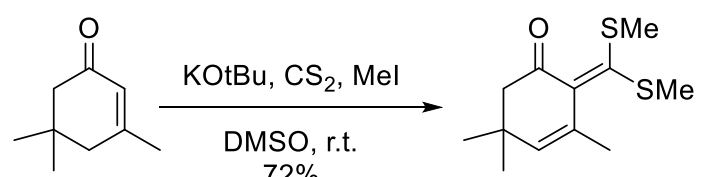
11 $72 \%$

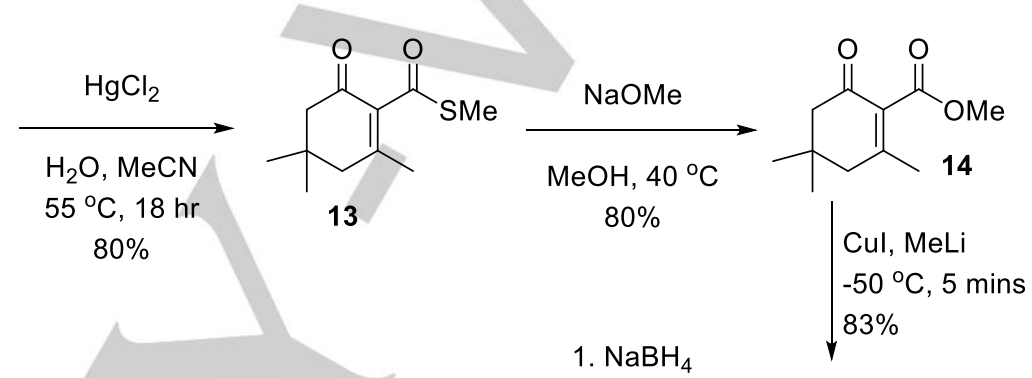<smiles>CC(=O)C1CCC(C)(C)CC1(C)C</smiles>

18<smiles>CC(=O)C1CCCCC1(C)C</smiles>

19

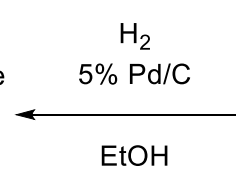

$50^{\circ} \mathrm{C}, 5$ bara $53 \%$
${ }^{\circ} \mathrm{C}, 18 \mathrm{hr}$ $80 \%$ $\mathrm{EtOH}, 0{ }^{\circ} \mathrm{C}$

$85 \%$

2. $\mathrm{MsCl}, \mathrm{NEt}_{3}$ $\mathrm{DCM}, 0^{\circ} \mathrm{C}$ $97 \%$<smiles>COC(=O)C1C(=O)CC(C)(C)CC1(C)C</smiles>

15
16

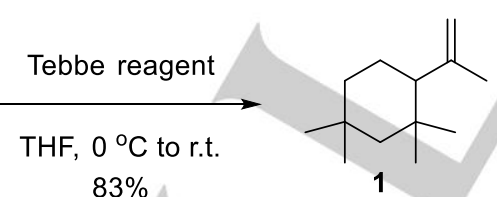

$83 \%$

\section{$\mathrm{C}_{13} \mathrm{H}_{24}$}

180.34

Scheme 5. Total synthesis of the C13 oligomer, 1.

\section{Conclusions}

In conclusion, we have reported the first de novo total synthesis of the $\mathrm{C} 13$ extractable/leachable oligomer, 1 . In completing the synthesis, we have also confirmed the proposed structure for this compound. The synthesis is robust and scalable, and provides material for extensive toxicity studies, in order to evaluate the potential dangers of this extractable and leachable compound in medical applications. 


\section{Experimental Section}

2-(Bis(methylthio)methylene)-3,5,5-trimethylcyclohex-3-en-1-one (12)

To a solution of potassium tert-butoxide ( $24.69 \mathrm{~g}, 220 \mathrm{mmol}, 2.2$ equiv) in dry DMSO (200.0 ml), isophorone 11 (13.82 g, $100.0 \mathrm{mmol}, 1.0$ equiv) was added portionwise and the dark red solution was stirred at room temperature for 30 minutes. Carbon disulfide $(8 \mathrm{~g}, 105.0 \mathrm{mmol}$, 1.05 equiv) was added in one portion (careful: very exothermic) and the dark brown solution was stirred for 30 minutes. Iodomethane $(31.22 \mathrm{~g}$, $220 \mathrm{mmol}, 2.2$ equiv) was added (careful: very exothermic) and the dark brown reaction was stirred at room temperature for $1 \mathrm{~h}$. Water $(20 \mathrm{ml})$ and $\mathrm{Et}_{2} \mathrm{O}(40 \mathrm{ml})$ were added to the reaction and the organic layer was separated and washed with saturated brine solution $(20 \mathrm{ml})$. The aqueous layers were combined and extracted with $\mathrm{Et}_{2} \mathrm{O}(10 \times 20 \mathrm{ml})$. The organic layers were combined, dried with $\mathrm{MgSO}_{4}$ filtered and the solvent was removed at reduced pressure. The crude oil was purified by flash column chromatography $\left(\mathrm{SiO}_{2}, 10 \% \mathrm{Et}_{2} \mathrm{O}\right.$ in Petrol, $\left.\mathrm{R}_{f}=0.3\right)$ to give the mixture of the two tautomers (endo:exo 92:8) of the title compound as a red thick oil (17.45 g, 72\%); major tautomer: IR $\left(\mathrm{cm}^{-1}\right)$ 1650, 1428, 1382,1362, 1339, 1300, 1253, 1197, 1137, 1115, 1045, 1005; ${ }^{1} \mathrm{H}$ NMR (500 MHz, $\left.\mathrm{CDCl}_{3}\right)$ $\delta 5.60(\mathrm{~d}, J=1.7 \mathrm{~Hz}, 1 \mathrm{H}), 2.41(\mathrm{~s}, 3 \mathrm{H}), 2.31(\mathrm{~s}, 2 \mathrm{H}), 2.24(\mathrm{~s}, 3 \mathrm{H}), 2.08$ (d, $J=1.7 \mathrm{~Hz}, 3 \mathrm{H}), 1.06(\mathrm{~s}, 6 \mathrm{H}) ;{ }^{13} \mathrm{C}$ NMR $\left(125 \mathrm{MHz} \mathrm{CDCl}_{3}\right) \delta 197.3,151.9$, 139.2, 133.0, 132.0, 51.7, 33.2, 28.5, 20.3, 19.9, 18.9; HRMS-ASAP $(\mathrm{m} / \mathrm{z})$ $[\mathrm{M}+\mathrm{H}]+$ calcd for $\mathrm{C}_{12} \mathrm{H}_{19} \mathrm{OS}_{2}$ requires 243.0872; found, 243.0868.

\section{S-Methyl 2,4,4-trimethyl-6-oxocyclohex-1-ene-1-carbothioate (13)}

To a dark red solution of 2-(bis(methylthio)methylene)-3,5,5trimethylcyclohex-3-en-1-one 12 (17.45 g, $72 \mathrm{mmol}, 1.0$ equiv) in water $(20 \mathrm{ml})$ and acetonitrile $(120 \mathrm{ml}), \mathrm{HgCl}_{2}$ was added $(21.50 \mathrm{~g}, 79.2 \mathrm{mmol}$, 1.1 equiv) and the reaction was stirred at $55^{\circ} \mathrm{C}$ until the starting material was completely consumed. The dark green/brown suspension was allowed to cool down to room temperature, filtered through a silica plug and the acetonitrile was removed at reduced pressure. The aqueous layer was extracted with dichloromethane $(2 \times 50 \mathrm{ml})$, dried with $\mathrm{MgSO}_{4}$ filtered and the solvent was removed at reduced pressure. The crude oil was purified by flash column chromatography $\left(\mathrm{SiO}_{2}, 10 \%\right.$ EtOAc in Petrol, $\mathrm{R}_{\mathrm{f}}=0.1$ ) to give the title compound as a crystalline yellow solid (12.23 g, 80\%); m.p.: $98-102{ }^{\circ} \mathrm{C}$; IR $\left(\mathrm{cm}^{-1}\right)$ 1659, 1621, 1422, 1377, 1359, 1308, 1150, 1113, 1023; ${ }^{1} \mathrm{H}$ NMR (500 MHz, $\left.\mathrm{CDCl}_{3}\right) \delta 2.37(\mathrm{~s}, 3 \mathrm{H}), 2.25(\mathrm{~s}, 2 \mathrm{H})$, $2.24(\mathrm{~s}, 2 \mathrm{H}), 1.93(\mathrm{~s}, 3 \mathrm{H}), 1.00(\mathrm{~s}, 6 \mathrm{H}) ;{ }^{13} \mathrm{C} \mathrm{NMR}\left(125 \mathrm{MHz}, \mathrm{CDCl}_{3}\right) \delta 195.4$ 194.2, 158.4, 137.1, 50.8, 46.2, 32.9, 28.2, 22.2, 12.2; $\operatorname{HRMS-ASAP}(\mathrm{m} / \mathrm{z})$ $[\mathrm{M}+\mathrm{H}]+$ calcd for $\mathrm{C}_{11} \mathrm{H}_{17} \mathrm{O}_{2} \mathrm{~S}$ requires 213.0944; found, 213.0943 .

\section{Methyl 2,4,4-trimethyl-6-oxocyclohex-1-ene-1-carboxylate (14)}

A solution of $\mathrm{NaH}(1.14 \mathrm{~g}, 60 \mathrm{mmol}, 1.04$ equiv) in dry $\mathrm{MeOH}(50 \mathrm{ml})$ at $0{ }^{\circ} \mathrm{C}$ was transferred to a solution of $S$-methyl 2,4,4-trimethyl-6oxocyclohex-1-ene-1-carbothioate $13(12.23 \mathrm{~g}, 57.6 \mathrm{mmol}, 1.0$ equiv) in dry $\mathrm{MeOH}(50 \mathrm{ml})$ and stirred at $40^{\circ} \mathrm{C}$ until the starting material was consumed. The reaction was allowed to cool down to room temperature, then a saturated solution of $\mathrm{NH}_{4} \mathrm{Cl}(20 \mathrm{ml})$ was added and the solvent was removed at reduced pressure. The aqueous layer was extracted with dichloromethane $(2 \times 50 \mathrm{ml})$, dried with $\mathrm{MgSO}_{4}$ filtered and the solvent was removed at reduced pressure. The crude oil was purified by flash column chromatography $\left(\mathrm{SiO}_{2}, 10 \%\right.$ EtOAc in Petrol, $\left.\mathrm{R}_{\mathrm{f}}=0.05\right)$ to give the title compound as a colourless oil $(9.04 \mathrm{~g}, 80 \%)$; IR $\left(\mathrm{cm}^{-1}\right) 1732,1667,1634$, $1435,1378,1369,1320,1279,1239,1196,1143,1068,1023 ;{ }^{1} \mathrm{H}$ NMR $\left(500 \mathrm{MHz}, \mathrm{CDCl}_{3}\right) \delta 3.79(\mathrm{~s}, 3 \mathrm{H}), 2.25(\mathrm{~s}, 2 \mathrm{H}), 2.25(\mathrm{~s}, 2 \mathrm{H}), 1.94(\mathrm{~s}, 3 \mathrm{H})$, $1.02(\mathrm{~s}, 6 \mathrm{H}) ;{ }^{13} \mathrm{C}$ NMR $\left(125 \mathrm{MHz}, \mathrm{CDCl}_{3}\right) \delta 195.4,167.3,158.6,131.9$,
52.2, 50.6, 45.9, 33.0, 28.2, 22.5; HRMS-ASAP $(\mathrm{m} / \mathrm{z})[\mathrm{M}+\mathrm{H}]+$ calcd for $\mathrm{C}_{11} \mathrm{H}_{17} \mathrm{O}_{3}$ requires 197.1172; found, 197.1170.

\section{Methyl 2,2,4,4-tetramethyl-6-oxocyclohexane-1-carboxylate (15)}

A suspension of $\mathrm{Cul}\left(9.65 \mathrm{~g}, 60.69 \mathrm{mmol}, 1.1\right.$ equiv) in dry $\mathrm{Et}_{2} \mathrm{O}(100 \mathrm{ml})$ was cooled to $-50^{\circ} \mathrm{C}$. Methyl lithium solution $\left(1.6 \mathrm{M}\right.$ in $\mathrm{Et}_{2} \mathrm{O}, 75.86 \mathrm{ml}$, $121.4 \mathrm{mmol}, 2.2$ equiv) was added and the reaction was left stirring at $-50{ }^{\circ} \mathrm{C}$ for 30 minutes. A solution of methyl 2,4,4-trimethyl-6-oxocyclohex1-ene-1-carboxylate 14 ( $9.04 \mathrm{~g}, 46.08 \mathrm{mmol}, 1.0$ equiv) in dry $\mathrm{Et}_{2} \mathrm{O}(40 \mathrm{ml})$ was added dropwise and the reaction was stirred at $-50{ }^{\circ} \mathrm{C}$ until the starting material was consumed. A saturated solution of $\mathrm{NH}_{4} \mathrm{Cl}(20 \mathrm{ml})$ was added and the reaction was allowed to warm up to room temperature, before filtering through a silica pad. The organic layer was separated, dried with $\mathrm{MgSO}_{4}$, filtered and the solvent was removed at reduced pressure. The crude oil was purified by flash column chromatography $\left(\mathrm{SiO}_{2}, 1 \% \mathrm{Et}_{2} \mathrm{O}\right.$ in Petrol, $\left.\mathrm{R}_{\mathrm{f}}=0.5\right)$ to give the title compound as a colourless oil $(8.118 \mathrm{~g}, 83 \%)$; major tautomer: IR $\left(\mathrm{cm}^{-1}\right)$ 1755, 1733, 1710 , 1633, 1599, 1459, 1436, 1391, 1371, 1344, 1316, 1276, 1229, 1197, 1154, 1098, 1037; ${ }^{1} \mathrm{H}$ NMR (500 MHz, $\left.\mathrm{CDCl}_{3}\right) \delta 3.64$ (s, 3H), 3.15 (s, $\left.1 \mathrm{H}\right), 2.57$ (d, $J=13.0 \mathrm{~Hz}, 2 \mathrm{H}), 2.32$ (d, $J=13.0 \mathrm{~Hz}, 2 \mathrm{H}), 1.85$ (d, $J=14 \mathrm{~Hz}, 2 \mathrm{H}$ ), 1.45 (d, $J=14.0 \mathrm{~Hz}, 2 \mathrm{H}), 1.07$ (s, 3H), 1.04 (s, 3H), 1.00 (s, 3H), 0.95 (s, $3 \mathrm{H}) ;{ }^{13} \mathrm{C} \mathrm{NMR}\left(125 \mathrm{MHz}, \mathrm{CDCl}_{3}\right) \delta 206.9,169.3,66.4,52.4,51.8,50.4$, $39.2,35.9,31.7,31.6,31.0,27.3$; HRMS-ASAP $(\mathrm{m} / \mathrm{z})[\mathrm{M}+\mathrm{H}]+$ calcd for $\mathrm{C}_{12} \mathrm{H}_{21} \mathrm{O}_{3}$ requires 213.1485; found, 213.1483.

\section{Methyl 6-hydroxy-2,2,4,4-tetramethylcyclohexane-1-carboxylate}

To a solution of methyl 2,2,4,4-tetramethyl-6-oxocyclohexane-1carboxylate $15(8.12 \mathrm{~g}, 38.24 \mathrm{mmol}, 1.0$ equiv) in dry $\mathrm{MeOH}(50 \mathrm{ml})$ at $0^{\circ} \mathrm{C}$, was added $\mathrm{NaBH}_{4}(1.74 \mathrm{~g}, 45.89 \mathrm{mmol}, 1.2$ equiv) and the reaction stirred until the starting material was consumed. A saturated solution of $\mathrm{NH}_{4} \mathrm{Cl}(20 \mathrm{ml})$ was added and the solvent removed at reduced pressure. The aqueous layer was extracted with $\mathrm{Et}_{2} \mathrm{O}(3 \times 30 \mathrm{ml})$, dried with $\mathrm{MgSO}_{4}$ filtered and the solvent was removed at reduced pressure. The crude oil was purified by flash column chromatography $\left(\mathrm{SiO}_{2}, 10 \%\right.$ EtOAc in Petrol, $\mathrm{R}_{\mathrm{f}}=0.3$ ) to give the mixture of the two diastereomers of the title compound as a white solid (6.97 $\mathrm{g}, 85 \%$ ). This was used immediately in the next step.

\section{Methyl 2,2,4,4-tetramethyl-6-((methylsulfonyl)oxy)cyclohexane-1- carboxylate (16)}

To a solution of the two diastereomers of methyl 6-hydroxy-2,2,4,4tetramethylcyclohexane-1-carboxylate $(6.97 \mathrm{~g}, 32.50 \mathrm{mmol}, 1.0$ equiv $)$ in dichloromethane $(50 \mathrm{ml})$ at $0^{\circ} \mathrm{C}$, triethylamine $(4.77 \mathrm{~g}, 47.13 \mathrm{mmol}$, 1.45 equiv) and methanesulfonyl chloride ( $5.58 \mathrm{~g}, 48.75 \mathrm{mmol}, 1.5$ equiv) were added and the reaction was left stirring for $3 \mathrm{~h}$. The reaction was allowed to warm up to room temperature, then a saturated solution of $\mathrm{NH}_{4} \mathrm{Cl}(20 \mathrm{ml})$ was added and the organic layer was separated. The aqueous layer was extracted with dichloromethane $(3 \times 30 \mathrm{ml})$, the organic layers were combined, dried with $\mathrm{MgSO}_{4}$ filtered and the solvent was removed at reduced pressure. The crude oil was purified by flash column chromatography $\left(\mathrm{SiO}_{2}, 10 \%\right.$ EtOAc in Petrol, $\left.\mathrm{R}_{\mathrm{f}}=0.3\right)$ to give the mixture of the two diastereomers of the title compound as a white solid $(9.27 \mathrm{~g}$, $97 \%$ ). This was used immediately in the next step.

\section{Methyl 4,4,6,6-tetramethylcyclohex-1-ene-1-carboxylate (17)}

A solution of $\mathrm{NaH}$ (983 mg, $40.1 \mathrm{mmol}, 1.3$ equiv) in dry $\mathrm{MeOH}(50 \mathrm{ml})$ at $0{ }^{\circ} \mathrm{C}$ was transferred to a solution of methyl 2,2,4,4-tetramethyl-6((methylsulfonyl)oxy)cyclohexane-1-carboxylate 16 (9.27 g, $31.52 \mathrm{mmol}$, 1.0 equiv) in dry $\mathrm{MeOH}(50 \mathrm{ml})$ and stirred at $40^{\circ} \mathrm{C}$ until the starting material was consumed. The reaction was allowed to cool down to room 
temperature, then a saturated solution of $\mathrm{NH}_{4} \mathrm{Cl}(20 \mathrm{ml})$ was added and the solvent was removed at reduced pressure. The aqueous layer was extracted with dichloromethane $(2 \times 50 \mathrm{ml})$, dried with $\mathrm{MgSO}_{4}$ filtered and the solvent was removed at reduced pressure. The crude oil was purified by flash column chromatography $\left(\mathrm{SiO}_{2}, 1 \% \mathrm{Et}_{2} \mathrm{O}\right.$ in Petrol, $\left.\mathrm{R}_{\mathrm{f}}=0.5\right)$ to give the title compound as a colourless oil $(5.07 \mathrm{~g}, 82 \%)$; IR $\left(\mathrm{cm}^{-1}\right) 1707,1459$, 1436, 1366, 1249, 1190, 1062; ${ }^{1} \mathrm{H}$ NMR $\left(500 \mathrm{MHz}, \mathrm{CDCl}_{3}\right) \delta 6.88$ (dd, $J=4.3 \mathrm{~Hz}, 1 \mathrm{H}) ; 1.94(\mathrm{~d}, J=4.3 \mathrm{~Hz}, 2 \mathrm{H}), 1.40(\mathrm{~s}, 2 \mathrm{H}), 1.24(\mathrm{~s}, 6 \mathrm{H}), 0.95$ (s, $6 \mathrm{H}) ;{ }^{13} \mathrm{C}$ NMR $\left(125 \mathrm{MHz}, \mathrm{CDCl}_{3}\right) \delta 167.6,138.6,136.7,53.5,51.2,40.4$ 33.7, 29.9, 29.8, 29.6; HRMS-ASAP $(m / z)[M+H]+$ calcd for $\mathrm{C}_{12} \mathrm{H}_{21} \mathrm{O}_{2}$ requires 197.1536; found, 197.1535 .

\section{Methyl 2,2,4,4-tetramethylcyclohexane-1-carboxylate (18)}

Methyl 4,4,6,6-tetramethylcyclohex-1-enecarboxylate $17(500 \mathrm{mg}, 2.55$ $\mathrm{mmol}), \mathrm{Pd} / \mathrm{C} 5 \%$ type 39 (250 mg, $0.5 \mathrm{wt}$ ) and ethanol $(5.00 \mathrm{~mL}$ ) were charged to each of 3 vessels of an HEL High Pressure ChemScan and hydrogenated at $50{ }^{\circ} \mathrm{C}, 5$ bara for $5 \mathrm{~h}$. Analysis by LCMS indicated incomplete conversion so the hydrogenation was continued for a further $16 \mathrm{~h}$ at $50^{\circ} \mathrm{C}$ and 5 bara, after which all reaction were judged complete by LCMS. The three reaction mixtures were combined and filtered through Celite, washing through with ethanol $(\sim 15 \mathrm{~mL})$. The filtrate was concentrated to an oil, during which a separate layer was observed. The material was redissolved in diethyl ether $(\sim 30 \mathrm{~mL})$ and dried over $\mathrm{Na}_{2} \mathrm{SO}_{4}$ to remove any residual water then filtered and again concentrated, controlling the vacuum to no more than $200 \mathrm{mbar}$ and the water bath to no more than $40^{\circ} \mathrm{C}$ to minimise loss of product. A small amount of a separate phase was again observed, for which NMR showed broad signals corresponding to expected peaks for ethanol. This was removed by pipette to leave methyl 2,2,4,4-tetramethylcyclohexane-1-carboxylate $(0.798 \mathrm{~g}$ $4.03 \mathrm{mmol}, 53 \%)$ as a colourless oil that was used directly in the next step. IR $\left(\mathrm{cm}^{-1}\right)$ 1733, 1458, 1434, 1388, 1365, 1325, 1293, 1248, 1213, 1172, 1147, 1034; ${ }^{1} \mathrm{H}$ NMR (500 MHz, $\left.\mathrm{CDCl}_{3}\right) \delta 3.62$ (s, 3H); 2.07 (dd, $J=12.5$ $3.5 \mathrm{~Hz}, 1 \mathrm{H}$ ), 1.82 (ddd, $J=27.2,13.8$ and $3.5 \mathrm{~Hz}, 1 \mathrm{H}), 1.60-1.54(\mathrm{~m}, 1 \mathrm{H})$, 1.47-1.41 (m, 1H), 1.27 (dd, $J=13.8,2.5 \mathrm{~Hz}, 1 \mathrm{H}), 1.14-1.05(\mathrm{~m}, 2 \mathrm{H}), 0.96$ $(\mathrm{s}, 6 \mathrm{H}), 0.95(\mathrm{~s}, 3 \mathrm{H}), 0.85(\mathrm{~s}, 3 \mathrm{H}) ;{ }^{13} \mathrm{C} \mathrm{NMR}\left(125 \mathrm{MHz}, \mathrm{CDCl}_{3}\right) \delta 175.5$, 54.0, 52.9, 51.0, 38.4, 34.5, 33.6, 33.2, 30.9, 27.2, 24.0, 22.6; HRMS-ASAP $(m / z)[M+H]+$ calcd for $\mathrm{C}_{12} \mathrm{H}_{23} \mathrm{O}_{2}$ requires 199.1693; found, 199.1691.

\section{1-(2,2,4,4-Tetramethylcyclohexyl)ethan-1-one (19)}

To a solution of $N, N$-dimethylethylenediamine $(265 \mathrm{mg} .3 .00 \mathrm{mmol}$, 1.1 equiv) in toluene $(20.0 \mathrm{ml})$ at $0^{\circ} \mathrm{C}$, a solution of trimethylaluminum (4.23 $\mathrm{ml}, 8.46 \mathrm{mmol}, 2.0 \mathrm{M}$ in toluene, 3.1 equiv) was added dropwise. The reaction mixture was stirred at room temperature for $1 \mathrm{~h}$ before adding a solution of methyl 2,2,4,4-tetramethylcyclohexane-1-carboxylate 18 (541 mg, $2.73 \mathrm{mmol}, 1.0$ equiv) in toluene $(5.0 \mathrm{ml})$. The resulting mixture was heated to reflux and was monitored via TLC ( $5 \% \mathrm{Et}_{2} \mathrm{O}$ in Petrol). The reaction mixture was cooled to room temperature and quenched with $1 \mathrm{~N}$ aqueous $\mathrm{HCl}$ solution. The organic layer was extracted with EtOAc $(3 \times 30 \mathrm{ml})$, dried with $\mathrm{MgSO}_{4}$, filtered and the solvent was removed at reduced pressure. The crude oil was purified by flash column chromatography $\left(\mathrm{SiO}_{2}, 5 \% \mathrm{Et}_{2} \mathrm{O}\right.$ in Petrol, $\left.\mathrm{R}_{\mathrm{f}}=0.2\right)$ to give the title compound as a colourless oil (148 mg, 30\%); IR $\left(\mathrm{cm}^{-1}\right)$ 1707, 1457, 1388, 1358, 1203, 1171; ${ }^{1} \mathrm{H}$ NMR (400 MHz, $\left.\mathrm{CDCl}_{3}\right) \delta 2.25$ (dd, $J=11.8,3.0 \mathrm{~Hz}$, $1 \mathrm{H}), 2.16(\mathrm{~s}, 3 \mathrm{H}), 1.85-1.71(\mathrm{~m}, 1 \mathrm{H}), 1.56-1.39(\mathrm{~m}, 2 \mathrm{H}), 1.34-1.07(\mathrm{~m}, 3 \mathrm{H})$, 1.03-0.94 (m, 9H), $0.88(\mathrm{~s}, 3 \mathrm{H}) ;{ }^{13} \mathrm{C}$ NMR (100 MHz, $\left.\mathrm{CDCl}_{3}\right) \delta 213.0,60.2$,
54.6, 38.7, 34.5, 34.1, 33.4, 32.2, 31.0, 27.4, 23.9, 22.5; HRMS-ASAP $(\mathrm{m} / \mathrm{z})[\mathrm{M}+\mathrm{H}]+$ calcd for $\mathrm{C}_{12} \mathrm{H}_{23} \mathrm{O}$ requires 183.1743; found, 183.1741.

\section{1,1,5,5-Tetramethyl-2-(prop-1-en-2-yl)cyclohexane (1)}

To a solution of 1-(2,2,4,4-tetramethylcyclohexyl)ethan-1-one 19 (148 mg, $0.813 \mathrm{mmol}, 1$ equiv) in THF $(5.0 \mathrm{ml})$ at $0{ }^{\circ} \mathrm{C}$ was added a toluene solution of the Tebbe reagent $(4.87 \mathrm{ml}, 2.44 \mathrm{mmol}, 3$ equiv). The reaction was allowed to stir at $0^{\circ} \mathrm{C}$ for 15 minutes, then to room temperature for $1 \mathrm{~h}$. The reaction was then cooled to $0^{\circ} \mathrm{C}$, diluted with $\mathrm{Et}_{2} \mathrm{O}(5.0 \mathrm{ml})$ and washed with a $0.1 \mathrm{M}$ aqueous solution of $\mathrm{NaOH}$ until gas evolution ceased. The reaction mixture was filtered through a silica pad, the organic layer extracted and dried over $\mathrm{MgSO}_{4}$. The crude oil was purified by flash column chromatography $\left(\mathrm{SiO}_{2}, 2 \% \mathrm{Et}_{2} \mathrm{O}\right.$ in Petrol, $\left.\mathrm{R}_{\mathrm{f}}=0.6\right)$ to give the title compound as a colourless oil (121 mg, $0.67 \mathrm{mmol}, 83 \%)$; IR $\left(\mathrm{cm}^{-1}\right) 1636$, 1455,$1376 ;{ }^{1} \mathrm{H}$ NMR $\left(400 \mathrm{MHz} \mathrm{CDCl}_{3}\right) \delta 4.83-4.80(\mathrm{~m}, 1 \mathrm{H}), 4.63-4.60(\mathrm{~m}$, $1 \mathrm{H}), 1.77-1.64(\mathrm{~m}, 5 \mathrm{H}), 1.49-1.42(\mathrm{~m}, 1 \mathrm{H}), 1.38-1.32(\mathrm{~m}, 1 \mathrm{H}), 1.27-1.11$ $(\mathrm{m}, 3 \mathrm{H}), 0.98(\mathrm{~s}, 3 \mathrm{H}), 0.93(\mathrm{~s}, 3 \mathrm{H}), 0.86(\mathrm{~s}, 6 \mathrm{H}) ;{ }^{13} \mathrm{C} \mathrm{NMR}(100 \mathrm{MHz}$, $\left.\mathrm{CDCl}_{3}\right) \delta 148.0,112.4,55.6,54.9,40.3,35.3,34.7,34.6,31.3$ 27.0, 25.4, 23.8, 23.6; HRMS-El (Waters GCT Premier Spectrometers) $(\mathrm{m} / \mathrm{z})$ [M] calcd for $\mathrm{C}_{13} \mathrm{H}_{24}$ requires 180.1878; found, 180.1877 .

\section{Acknowledgements}

We wish to thank GlaxoSmithKline for funding of this project, and for a postdoctoral fellowship to F.M. The EPSRC National Mass Spectrometry Service (Swansea) is greatfully acknowledged for running some mass spectra.

Keywords: C13 butylrubber oligomer $\cdot$ dithioacetal $\bullet$ isophorone - Tebbe reagent $\bullet$ hydrogenation

I. Kuntz, K. W. Powers, C. S. Hsu and K. D. Rose, Makromolekulare Chemie-Macromolecular Symposia, 1988 13-4, 337-362.

2. https://nelsonlabs.be/services/EandL Rubber Oligomers.cfm (accessed 9.3.2018).

3. G. A. Molander and J. A. McKie, J. Org. Chem., 1991, 56, 4112-4120.

4. R. K. Dieter and J. W. Dieter, .Chem. Commun. 1983, 13781380.

5. R. K. Dieter, Y. J. Lin and J. W. Dieter, J. Org. Chem., 1984 49, 3183-3195.

6. B. M. Trost and G. M. Schroeder, J. Am. Chem. Soc., 1999, 121, 6759-6760.

7. C. A. Elliger, M. Benson, W. F. Haddon, R. E. Lundin, A. C Waiss and R. Y. Wong, J. Chem. Soc. Perkin Trans. 1, 1989, 143-149.

8. M. Brindisi, S. Gemma, S. Kunjir, L. Di Cerbo, S. Brogi, S. Parapini, S. D'Alessandro, D. Taramelli, A. Habluetzel, S. Tapanelli, S. Lamponi, E. Novellino, G. Campiani and S. Butini, MedChemComm, 2015, 6, 357-362. 
Entry for the Table of Contents (Please choose one layout)

\section{FULL PAPER}

The first total synthesis of important C13 butyl rubber oligomers is reported. The structure of the oligomer, which is an important extractable and leachable component of elastomeric closures, is confirmed for the first time. The 10-step synthetic sequence starting from isophorone is robust and scalable, making large quantities of the oligomer available for the first time.

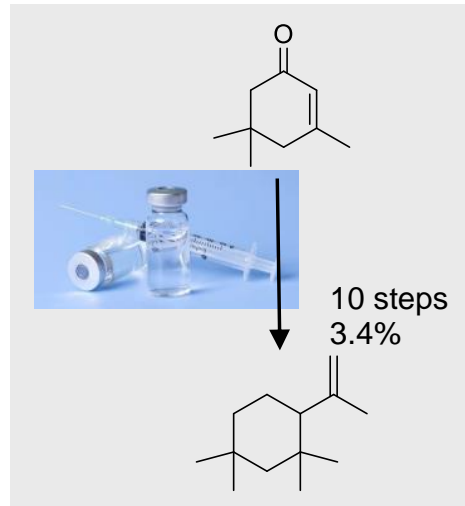

Extractable and leachable oligomers; C13-butyl rubber oligomers; total synthesis; structural confirmation; dithioacetal; Tebbe olefination

Fabrizio Minicone, Robin Attrill, Michael Hodgson, Katherine Wheelhouse, Adrian Dobbs*

Page No. - Page No.

First Total Synthesis and Structural Confirmation of C13-Butylrubber Oligomers 